\title{
Brexit: the decision of a divided country
}

\author{
Blame austerity not immigration for the inequality underlying the referendum decision
}

\author{
Danny Dorling Halford Mackinder professor of geography \\ School of Geography and the Environment, University of Oxford, Oxford OX1 3QY, UK
}

On the same day that the United Kingdom voted to leave the EU, huge rises in UK death rates were reported. These rises followed the austerity policies enacted by the 2010 coalition government. ${ }^{1}$ Self reported health was a key component of David Cameron's wellbeing index, and it has declined in every year of his premiership, most rapidly towards the end. ${ }^{2}$ In March 2016 the Office for National Statistics (ONS) reported: "The proportion of people aged 16 and over in the UK who were somewhat, mostly or completely satisfied with their health was lower in the financial year ending 2014 (57.8\%) than in the previous year $(59.3 \%)$. The way in which people view their health is crucial to well-being."

Brandishing the slogan "Vote leave, take control," the Leave campaign secured $51.9 \%$ of the referendum vote. However, 13 million registered voters did not vote, and a further seven million eligible adults were not registered. ${ }^{5}$ They were disproportionately "the young; flat-dwellers, especially renters; members of ethnic minorities; [and] recent movers."

The outcome of the EU referendum has been unfairly blamed on the working class in the north of England, and even on obesity. ${ }^{7}$ However, because of differential turnout and the size of the denominator population, most people who voted Leave lived in the south of England. ${ }^{8}$ Furthermore, of all those who voted for Leave, $59 \%$ were in the middle classes (A, B, or C1). The proportion of Leave voters in the lowest two social classes (D and E) was just $24 \% .{ }^{8}$ The Leave voters among the middle class were crucial to the final result because the middle class constituted two thirds of all those who voted.

\section{High price of austerity}

On the day of the EU referendum, data released from the ONS showed there had been 52400 more deaths in the year to June 2015 compared with the year to June $2014 .{ }^{9}$ Death rates in England and Wales rose overall by $9 \%$. The biggest increases were among older adults and were unprecedented. They were attributed to dementia and Alzheimer's disease, with influenza being suggested as a contributory factor. ${ }^{10}$ Austerity had a major role, with people who had long term care needs dying earlier. ${ }^{11}$ The health and social services crises will deepen as national finances deteriorate and as it becomes harder to recruit and retain staff from the European mainland. ${ }^{12}$
Most migrants to the UK have good health and settle in poorer areas. The only adult age group to see improvements in death rates in the year to mid-2015 were those aged 25-29. The mid-year estimates released on 23 June 2016 showed that this was the age group of highest net in-migration to the UK. ${ }^{9}$ The UK has benefited greatly from the immigration of healthier than average young adults, educated at someone else's expense; many of them work in our health, educational, social, and care services. Their arrival reduced heath inequalities and improved our overall health.

The underlying reason for worsening health and declining living standards was not immigration but ever growing economic inequality and the public spending cuts that accompanied austerity. Almost all other European countries tax more effectively, spend more on health, and do not tolerate our degree of economic inequality. ${ }^{13}$ To distract us from these national failings, we have been encouraged to blame immigration and the EU. That lie will now be exposed.

Most people younger than 50 who voted, voted to remain. They voted for a more inclusive politics, against bigotry, and for tolerance. They will feel newly betrayed by older voters, but their real betrayal has been a long time in the making. In contrast to other European states, the UK has been systematically underfunding education and training, increasing student loans and debt, tolerating increasingly unaffordable housing, introducing insecure work contracts, and privatising the services the young will need in future. We encouraged the young to become individualistic and then blamed them when they did not turn out to vote in sufficient numbers. They blame the older generation, but their ire should instead be directed at the post-1979 UK governments that have allowed economic inequalities to rise so high; that prevented a fair proportional voting system being introduced; and that have placed future generations in peril.

I thank Nuala Burgess, David Dorling, George Davey Smith, Dominic Harrison, Ben Hennig, Aniko Horvath, Jon Minton, Andrew Moscrop, Kate Pickett, and the staff at The BMJ for comments on earlier versions of this editorial. 
Competing interests: I have read and understood BMJ policy on declaration of interests and declare I am a trustee of St Peter's College, Oxford.

Provenance and peer review: Commissioned; not externally peer reviewed.

1 Dorling D, Thomas B. People and places: a 21st-century atlas of the UK. Policy Press, 2016:186-9.

2 ONS. Measuring national well-being: domains and measures, March 2015 release. Section 3.3 satisfaction with general health. 2015. https://www.ons.gov.uk/

peoplepopulationandcommunity/wellbeing/datasets/

measuringnationalwellbeingdomainsandmeasures

3 ONS. Measuring national wellbeing: life in the UK: 23 March 2016. http://www.ons.gov. uk/peoplepopulationandcommunity/wellbeing/articles/measuringnationalwellbeing/2016 Why vote Leave. http://www.voteleavetakecontrol.org/

5 Whatever your views on the EU, make sure you are registered to vote. Independent 2016 Jun7. http://www.independent.co.uk/voices/editorials/eu-referendum-brexit-register-tovote-registration-deadline-young-voters-a7056886.html

6 Johnston R, Pattie C, Rossiter D. Ensuring equal representation in parliament: who counts? LSE British policy and politics blog, 20 Jul 2015. http://blogs.Ise.ac.uk/politicsandpolicy/ ensuring-equal-representation-in-parliament-who-counts/
7 Ormosis PK. The weight of Brexit: obese adults leading the way out of Europe, 29 Jun 2016.

https://omosi wordpress com/2016/06/29/the-weight-of-brexit-obese-adults-lead-the-way-out-of-europe.

8 Ashcroft M. How the United Kingdom voted on Thursday... and why, Lord Ashcroft polls, 24 Jun 2016. http://lordashcroftpolls.com/2016/06/how-the-united-kingdom-voted-andwhy

9 ONS. Population estimates for UK, England and Wales, Scotland and Northern Ireland: mid-2015. 2016. https://www.ons.gov.uk/peoplepopulationandcommunity/ populationandmigration/populationestimates/bulletins/annualmidyearpopulationestimates/ latest

10 ONS. Dementia/Alzheimer's and respiratory disease behind biggest annual increase in deaths since the 1960s. 2016. http://visual.ons.gov.uk/dementiaalzheimers-and-flu-behindbiggest-annual-increase-in-deaths-since-the-1960s/

11 Dorling $\mathrm{D}$. Why are the old dying before their time? How austerity has affected mortality rates. New Statesman 2014 Feb 7. http://www.newstatesman.com/politics/2014/02/whyare-old-people-britain-dying-their-time

2 Rylands-Monk F. EU nationals voice anxiety post-Brexit: the 280 or so radiologists from other EU countries who are working in the UK. AuntMinnie Europe 2016 Jun 29. http:// www.auntminnieeurope.com/index.aspx?sec=ser\&sub=def\&pag=dis\&ltemID=613177

13 Dorling D. Conclusion. In: A better politics: how government can make us happier. London Publishing Partnership, 2016:132-45. http://www.dannydorling.org/books/betterpolitics/.

Published by the BMJ Publishing Group Limited. For permission to use (where not already granted under a licence) please go to http://group.bmj.com/group/rights-licensing/ permissions 